\title{
МОРФОЛОГІЧНІ ОСОБЛИВОСТІ ЕНДОМЕТРІЯ У ЖІНОК РЕПРОДУКТИВНОГО ВІКУ: АНАЛІЗ МОРФОМЕТРИЧНИХ ПОКАЗНИКІВ
}

\author{
ФГ. М. Чорненька', М. В. Логаш ${ }^{2}$
}

ДВНЗ «Тернопільський державний медичний університет імені І. Я. Горбачевського МОЗ України»' 2Львівський національний медичний університет імені Данила Галицького ${ }^{2}$

РЕзЮмЕ. Ендометрій - це головна структура у реалізації імплантації, яка зазнає постійних морфофункціональних змін, а його адекватні стан та прегравідарна трансформація $\epsilon$ необхідними умовами для нормального розвитку вагітності, надто в її першому триместрі. Дослідження особливостей морфологічної структури нормального ендометрія із застосуванням сучасних морфометричних методів $\epsilon$ необхідним для розуміння суті патологічних процесів фукціонального шару матки, розвиток яких може перешкоджати настанню вагітності.

Матеріал і методи. Для морфометричного дослідження використовували гістологічні препарати функціонального шару матки 20 жінок репродуктивного віку із нормальним ендометрієм у фазах проліферації та секреції. Виконували серійні поступові зрізи з парафінових блоків товщиною 2-4 мікрона, зафарбовували за стандартною методикою гематоксиліном і еозином. Проводили замір та аналіз діаметра залоз ендометрія, товщини стінки залоз, співвідношення площі перерізу залоз до площі ендометрія.

Результати. У результаті морфометричного дослідження гістологічних препаратів функціонального шару матки у жінок репродуктивного віку, із нормальним менструальним циклом, середній вік яких становив (32 \pm 10$)$ років, з'ясовано, що результати морфологічного дослідження можуть використовуватись з метою аналітичного дослідження як фізіологічної, так і патологічної трансформативності ендометрія людини.

Діаметр залоз ендометрія у фазі проліферації коливався в межах 28,29-70,29 мкм при значенні IQR=21,94. Tовщина стінки була рівномірна і їі значення становили $(15,02 \pm 3,61)$ мкм. Співвідношення площі перерізу залоз до площі перерізу паренхіми були рівномірними у всьому зразку і коливалися в межах від 7 \% до 13 \% із середнім значенням $10 \%$.

При морфометричному дослідженні поліморфність залозистих структур ендометрія секреторного типу підтверджується певними показниками: діаметр залоз становить $71,81(47,71 ; 83,95)$ мкм та коливається від 33,39 мкм до 125,02 мкм при значенні IQR=36,24. Збільшення діаметра, порівняно з показниками у фазі проліферації, є статистично достовірним ( $<<0,05$ при точному значенні критерію Манна-Уіттні $U=72$ ). Товщина стінок залоз при цьому дещо зменшилась і становила $(13,13 \pm 3,37)$ мкм, що було статистично достовірно менше показника товщини у фазі проліферації. Розташовувались залози більш хаотично, порівняно із зразками фази проліферації,-показник співвідношення площі перерізу залоз до площі перерізу паренхіми коливався від 17 \% до 52 \% із середнім значенням 32 \% (різниця статистично достовірна, p<0,05 при значенні $\chi^{2}=97$ ).

Висновки. Морфологічній структурі ендометрія жінок репродуктивного віку притаманні не лише гістологічні, а й морфометричні відмінності. Отримані нами дані свідчать про достовірну різницю основних морфометричних показників залоз слизової матки в проліферативній та секреторній фазах менструального циклу в нормі.

Перспективи подальших досліджень. Морфологічна структура ендометрія за умов норми та патології вимагає нових підходів із застосуванням сучасних доступних методів, необхідних для розуміння суті патологічних процесів фукціонального шару матки, особливо у жінок репродуктивного віку, що звертаються з приводу непліддя, спричиненого матковим фактором.

КлючовІ СлОВА: ендометрій; проліферація; секреція; репродуктивний вік; морфометрія.

Вступ. Ендометрій - це головна структура у реалізації імплантації. Адекватні стан ендометрію та його прегравідарна трансформація $\epsilon$ необхідними умовами для нормального розвитку вагітності, надто в її першому триместрі [8]. Відомим $\epsilon$ той факт, що функціональний шар матки зазнає постійних морфофункціональних змін впродовж менструального циклу, які відбуваються завдяки гормональній регуляції. Такі циклічні зміни ендометрія, під час яких відбувається проліферація і диференціювання епітеліальних клітин та пов'язаної з ними сполучної тканини, необхідні для забезпечення успішного настання вагітності. Тому особливу увагу приділяють морфологічному оцінюванню ендометрія в 7-10 постовуляторні дні, відповідні 21-24 дням «класичного» 28 денного менструального циклу, який часто називають «вікно імплантації» $[4,5]$.

Науковці-морфологи встановили, що паренхіматозним компонентом ендометрія $\epsilon$ маткова залоза, яка скаладається з просвіту залози та ії епітелію, а епітеліально-стромальні взаємовідношення у слизовій матки забезпечують нормальне ії̈ функціонування [6].

Будь-які порушення проліферативної активності клітин ендометрія ведуть до виникнення гіперпластичних процесів у цій матковій структурі. Питанням патологічної модифікації слизової матки присвячено багато наукових праць, тому, дослідження особливостей морфологічної структу- 
Огляди літератури, оригінальні дослідження, погляд на проблему, ювілеї

ри нормального ендометрія із застосуванням сучасних морфометричних методів $\epsilon$ необхідним для розуміння суті патологічних процесів фукціонального шару матки.

Матеріал і методи дослідження. Для морфометричного дослідження використовували гістологічні препарати функціонального шару матки 20 жінок репродуктивного віку. Матеріал для дослідження отримано при діагностичному вишкрібанні. Критеріями вибору матеріалу для дослідження були нормальна будова ендометрія у відповідних фазах менструального циклу - проліферації та секреції. Виняток становили зразки ендометрія із гіперпластичними та гіперпроліферативними процесами. Виконували серійні поступові зрізи з парафінових блоків товщиною 2-4 мікрона, які зафарбовували за стандартною методикою гематоксиліном і еозином. Проводили замір та аналіз наступних параметрів - діаметр залоз ендометрія, товщина стінки залоз, співвідношення площі перерізу залоз до площі ендометрія. Для дослідження препарати фотографували з використанням мікроскопа Mеiji 4300 LED, об'єктива х40, фотоапарата Canon 550D з перехідником MA150/50 та адаптером МА986 із збільшенням х1.9, калібрувальні знімки для проведення морфометрії виготовлено за допомогою слайду Меiji МА285. Всі подальші дослідження проводилися виключно із первинними, нередагованими знімками формату Jpeg роздільною здатністю 5184х3456. Заміри лінійних показників проводили з використанням програми ImageJ ver.1.48u [1, 2] з використанням інструменту "straight line", визначення співвідношення перерізів проводили за допомогою програмного забезпечення Stepanizer ver.2.28 [3] із використанням тестової сітки на 144 та 36 точок. Результати замірів зберігали у формі електронних таблиць із подальшим аналізом з використанням Microsoft Office Excel 2016 та RStudio v.1.1.442 з графічною оболонкою R Commander ver. 2.4-4.

Вибір методу представлення даних та методик для статистичної обробки залежав від типу розподілу даних в отриманих вибірках. У випадку відповідності даних нормальному типу розподілу використовували середнє та стандартне відхилення у вигляді $\mathrm{M} \pm \mathrm{SD}$ для представлення даних та t критерій для непов'язаних вибірок для виявлення статистичної достовірності. Якщо дані не відповідали критеріям нормальності розподілу, використовували медіану та квартилі для представлення даних у вигляді Ме (25 \%; 75 \%) із додатковим використанням міжквартильного розмaxy (IQR) як параметра варіативності, та U критерія Манна-Уїттні для виявлення достовірності різниці між групами. Для визначення достовірності різниці параметрів співвідношення вико- ристовували таблиці частот та критерій ксі-квадрат Пірсона. Рівень достовірності встановлений на рівні $p<0,05$.

Результати й обговорення. Для морфометричного дослідження використовували гістологічні препарати функціонального шару матки 20 жінок репродуктивного віку із нормальним менструальним циклом, середній вік яких становив $32 \pm 0$ років. Ендометрій був у стані фізіологічної проліферативної фази маткового циклу 11 випадків, та фази секреції - 9 випадків.

У гістологічних препаратах матки жінок, що були отримані в проліферативній фазі менструального циклу (11 випадків), морфологічна картина була наступною. В двох випадках морфологічна структура ендометрія відповідала середньопроліферативному, в дев'яти - пізньопроліферативному ендометрію.

Дослідження ендометрія в першу половину менструального циклу вважають малоінформативним, оскільки складно встановити, чи є даний цикл двофазним, овуляторним чи спостерігається ановуляція, частота якої зростає з віком жінки, особливо в період пременопаузи. В основному діагностичне вишкрібання ендометрія в фолікулярній фазі циклу рекомендоване при підозрі на хронічний ендометрит, оскільки 8-11 дні менструального циклу характеризуються найнижчим вмістом лімфоцитів у стромі функціонального шару матки [5].

Для подальших досліджень, на основі аналізу гормональної регуляції метаморфозу ендометрія, ми відібрали ендометрій, що відповідав пізній стадії проліферації та середньосекреторній фазі. Пізньопроліферативна фаза менструального циклу $\epsilon$ найінформативнішою щодо гормонально-естрогенного впливу, тоді як морфологічна картина середньосекреторного ендометрія $\epsilon$ “дзеркалом" прогестеронової функції.

Зважаючи на те, що естрогени є стимуляторами синтезу прогестеронових рецепторів, їх попередній вплив є важливим у настанні фази проліферації, адже дозволяє провести підготовку ендометрія до впливу прогестерону у фазі секреції. Тому морфофізіологічні зміни ендометрія, що характерні для проліферативної фази, мають вирішальну підготовчу роль для настання подальшої успішної фази секреції.

Гістологічна картина ендометрія стадії пізньої проліферації була наступною. Поверхневий епітелій циліндричний з миготливими клітинами. Залози звивисті, з інтенсивними проявами проліферації, порівняно зі стромою. Епітелій залоз багаторядний, мітотично активний, вогнищево наявні патологічні мітози, апікальні краї клітин рівні. Ядра клітин округлі та видовжені, парабазально 
Огляди літератури, оригінальні дослідження, погляд на проблему, ювілеї

дислоковані, цитоплазма базофільна, ядерно-цитоплазматичне співвідношення в епітеліальних клітинах знижене. Строма ендометрія компактна, вогнищево зустрічаються вогнища набряку, переважно у поверхневому відділі, представлена фібробластоподібними округлими клітинами із круглими ядрами та базофільною цитоплазмою. Екстрацелюлярно - густа сітка ретикулінових волокон.

При морфометричному аналізі з'ясовано наступне - діаметр залоз коливався в межах 28,2970,29 мкм при значенні IQR=21,94. Товщина стінки рівномірна і їі значення становить $(15,02 \pm$ $3,61)$ мкм. Співвідношення площі перерізу залоз до площі перерізу паренхіми $\epsilon$ рівномірним протягом зразків і коливається в межах від 7 \% до $13 \%$ із середнім значенням $10 \%$.

У гістологічних препаратах ендометрія, що були отримані у фазу секреції менструального циклу, з дев'яти випадків у одному ендометрій відповідав ранньосекреторному типу, у семи - середньосекреторному, та у одному випадку - пізньосекреторному типу.

При оцінюванні функціонального шару матки секреторного типу ми акцентували увагу на ендометрію середньої секреторної стадії, як найінформативнішої щодо готовності ендометрія до успішного настання вагітності.

Ендометрій середньої стадії секреції мав наступні характерні морфологічні особливості. За- лози ендометрія були поліморфними на розрізі рідше округлі, частіше овальні, хробакоподібні, гачкоподібні та інших форм, звивисті із широким просвітом, виповнені секретом у різних кількостях. Епітеліальні структури залозистих крипт із везикулярними, світлими, базально-дислокованими ядрами та нерівними апікальними краями. Строма слизової матки пухка, із вираженим набряком, представлена переважно округлими та полігональними клітинними комплексами, клітин звичної веретеноподібної форми мало. Виражена звивистість судин, що представлені спіральними артеріями.

При морфометричному дослідженні поліморфність залозистих структур ендометрія секреторного типу підтверджується певними показниками:діаметр залоз становить 71,81 (47,71; $83,95)$ мкм та коливається від 33,39 мкм до 125,02 мкм при значенні IQR=36,24. Товщина стінок залоз при цьому дещо зменшилась і становила $(13,13 \pm 3,37)$ мкм, що було статистично достовірно менше показника товщини у фазі проліферації. Розташовувались залози більш хаотично, порівняно із зразками фази проліферації, - показник співвідношення площі перерізу залоз до площі перерізу паренхіми коливався від $17 \%$ до 52 \% із середнім значенням 32 \% (різниця статистично достовірна, $p<0,05$ при значенні $\left.\chi^{2}=97\right)$. Результати морфометричного дослідження наведені у таблиці 1.

Таблиця 1. Зведені дані морфометричного дослідження ендометрія

\begin{tabular}{|l|c|c|c|}
\hline \multicolumn{1}{|c|}{ Фаза } & Діаметр залоз, мкм & Товщина стінки, мкм & $\begin{array}{c}\text { Співвідношення до } \\
\text { ендометрія, \% }\end{array}$ \\
\hline Фаза проліферації & $40,39(31,04 ; 52,98)$ & $15,02 \pm 3,61$ & 10 \\
\hline Фаза секреції & $71,81(47,71 ; 83,95)$ & $13,13 \pm 3,27$ & 32 \\
\hline $\begin{array}{l}\text { Результати перевірки } \\
\text { достовірності }\end{array}$ & $\mathrm{p}<0,001, \mathrm{U}=72$ & $\mathrm{p}=0,043, \mathrm{t}=2,07$ & $\mathrm{p}<0,001, \chi^{2}=9$ \\
\hline
\end{tabular}

Висновки. 1. Для ендометрія проліферативного типу морфометричне співвідношення площі перерізу залоз до площі перерізу паренхіми $\epsilon$ рівномірним протягом зразків і коливається в межах від $7 \%$ до $13 \%$ із середнім значенням $10 \%$, тоді як для ендометрія секреторного типу середній показник становить $32 \%$.

2. При морфометричному дослідженні гістополіморфність залозистих структур ендометрія секреторного типу підтверджується певними показниками: діаметр залоз становить $71,81(47,71$; $83,95)$ мкм та коливається від 33,39 мкм до 125,02 мкм при значенні IQR=36,24.

3. Отримані дані свідчать про достовірну різницю основних морфометричних показників за- лоз слизової матки в проліферативну та секреторну фази менструального циклу в нормі.

4. Результати дослідження можуть бути використані для порівняння морфометричної картини нормального та патологічно зміненого ендометрія.

Перспективи подальших досліджень. Вивчення морфологічної структури ендометрія за умов норми та патології вимагає нових підходів із застосуванням сучасних доступних методів, нео6хідних для розуміння суті патологічних процесів фукціонального шару матки, особливо у жінок репродуктивного віку, що звертаються з приводу непліддя, спричиненого матковим фактором. 
Огляди літератури, оригінальні дослідження, погляд на проблему, ювілеї

\section{ЛІТЕРАТУРА}

1. Abràmoff M. D. Image processing with Image / M. D. Abràmoff, P. J. Magalhães, S. J. Ram // J. Biophotonics Int. - 2004. - Vol. 11 (7). - P. 36-42.

2. NIH Image to ImageJ: 25 years of image analysis / C. A. Schneider, W. S. Rasband, K. W. Eliceiri [et al.] // Nat. Methods. - 2012. - Vol. 9 (7). - P. 671-675.

3. Tschanz S. A simple tool for stereological assessment of digital images: the STEPanizer / S. Tschanz, P. Burri, E. Weibel // J. Microsc. - 2011. - Vol. 243

4. Crum C. P. Evolution of cyclic endometrium and, benign endometrial disorders. In: Diagnostic ginecologic and obstetric pathology / C. P. Crum, K. L. Lee // Elsevier
Sanders. - 2006. - P. 441-488.

5. Дубницкая Л. В. Хронический эндометрит: возможности диагностики и лечения / Л. В. Дубницкая, Т. А. Назаренко // Consilium Medicum. - 2007. - T. 9, № 6. C. 25-28.

6. Кондриков Н. И. Патология матки / Н. И. Кондриков. - М. : Практическая медицина, 2008. - 334 с.: ил.

7. Захаренко Н. Ф. Імуногістохімічні маркери проліферації та апоптозу ендометрію у жінок з ендометріозом різної локалізації / Н. Ф. Захаренко, Т. Д. Задорожна, Л. В. Калугіна // Здоровье женщины. - 2012. № 10 (78). - C. 98-100

\title{
REFERENCES
}

1. Abràmoff, M.D., Magalhães, P.J., \& Ram, S.J. (2004). Image processing with Image J. Biophotonics Int., 11 (7), 36-42.

2. Schneider, C.A., Rasband, W.S., \& Eliceiri, K.W. (2012). NIH Image to ImageJ: 25 years of image analysis. Nat. Methods, 9 (7), 671-675.

3. Tschanz, S., Burri, P., \& Weibel, E. (2011). A simple tool for stereological assessment of digital images: the STEPanizer. J. Microsc., 243

4. Crum, C.P., \& Lee, K.L. (2006). Evolution of cyclic endometrium and, benign endometrial disorders. In: Diagnostic ginecologic and obstetric pathology. Elsevier Sanders.

5. Dubnitskaya, L.V., \& Nazarenko, T.A. (2007). Khronicheskiy endometrit: vozmozhnosti diagnostiki i

lecheniya [Chronic endometritis: diagnostic and treatment options]. Consilium Medicum, 9 (6), 25-28 [in Russian].

6. Kondrikov, N.I. (2008). Patologiya matki [Pathology of the uterus]. Moscow: Prakticheskaya meditsina [in Russian].

7. Kondrikov, N.I. (2008). Patologiya matki [Pathology of the uterus]. Moscow: Prakticheskaya meditsina [in Russian].

8. Zakharenko, N.F. (2012.) Imunohistokhimichni markery proliferatsii ta apoptozu endometriiu u zhinok z endometriozom riznoi lokalizatsii [Immunohistochemical markers of proliferation and apoptosis of endometrium in women with endometriosis of different localization]. Zdorovye zhenshchiny - Women's Health, 10 (78), 98-100 [in Ukrainian].

\section{МОРФОЛОГИЧЕСКИЕ ОСОБЕННОСТИ ЭНДОМЕТРИЯ У ЖЕНЩИН РЕПРОДУКТИВНОГО ВОЗРАСТА: АНАЛИЗ МОРФОМЕТРИЧЕСКИХ ПОКАЗАТЕЛЕЙ}

\author{
○Г. Н. Чорненька', М. В. Логаш ${ }^{2}$
}

Тернопольський государственный медицинский университет имени И. Я. Горбачевского Львовский национальный медицинский университет имени Данила Галицкого 2

РЕЗЮМЕ. Эндометрий - это главная структура в реализации имплантации, которая подвергается постоянным морфофункциональным изменениям, а его адекватные состояние и прегравидарная трансформация являются необходимыми условиями для нормального развития беременности, особенно в ее первом триместре. Исследование особенностей морфологической структуры нормального эндометрия с применением современных морфометрических методов необходимо для понимания сути патологических процессов фукционального слоя матки, развитие которых может препятствовать наступлению беременности.

Материал и методы. Для морфометрического исследования использовались гистологические препараты функционального слоя матки 20 женщин репродуктивного возраста с нормальным эндометрием фазы пролиферации и секреции. Выполнялись серийные постепенные срезы с парафиновых блоков толщиной 2-4 мкн, окрашивание по стандартной методике гематоксилином и эозином. Проводили замер и анализ диаметра желез эндометрия, толщины стенки желез, соотношение площади сечения желез к площади эндометрия.

Результаты. В результате морфометрического исследования гистологических препаратов функционального слоя матки у женщин репродуктивного возраста с нормальным менструальным циклом, средний возраст которых составлял (32+10) лет, выяснилось, что результаты морфологического исследования могут использоваться с целью аналитического исследования как физиологической, так и патологической трансформативности эндометрия человека.

У эндометрия фазы пролиферации диаметр желез колебались в пределах 28,29-70,29 мкм, при значении $\mathrm{IQR}=21,94$. Толщина стенки была равномерной и ее значение составляло $(15,02 \pm 3,61)$ мкм. Соотношения площади сечения желез к площади сечения паренхимы были равномерными в течение образцов и колебались в пределах от 7 \% до 13 \% со средним значением $10 \%$. 
Огляди літератури, оригінальні дослідження, погляд на проблему, ювілеї

При морфометрических исследованиях полиморфность железистых структур эндометрия секреторного типа подтверждается определенными показателями: диаметр желез составляет $71,81(47,71 ; 83,95)$ мкм и колеблется от 33,39 мкм до 125,02 мкм при значении IQR = 36,24. Увеличение диаметра, по сравнению с показателями фазы пролиферации, является статистически достоверным ( $<<0,05$ при строгом смысле критерия Мана-Уитни U = 72). Толщина стенок желез при этом несколько уменьшилась и составила $(13,13 \pm 3,37)$ мкм, что было статистически достоверно меньше показателя толщины в фазе пролиферации. Располагались железы более хаотично, по сравнению с образцами фазы пролиферации, - показатель соотношения площади сечения желез к площади сечения паренхимы колебался от $17 \%$ до 52 \%, со средним значением 32 \% (разница статистически достоверна, р<0,05 при значении $\chi^{2}=97$ ).

Выводы. Морфологической структуре эндометрия женщин репродуктивного возраста присущи не только гистологические, но и морфометрические различия. Полученные нами данные свидетельствуют о достоверной разнице основных морфометрических показателей желез слизистой матки в пролиферативную и секреторную фазы менструального цикла в норме.

Перспективы дальнейших исследований. Морфологическая структура эндометрия в условиях нормы и патологии требует новых подходов с применением современных доступных методов, необходимых для понимания сути патологических процессов фукционального слоя матки, особенно у женщин репродуктивного возраста, обращающихся по поводу бесплодия, вызванного маточным фактором.

КЛЮЧЕВЫЕ СЛОВА: эндометрий, пролиферация, секреция, репродуктивный возраст, морфометрия.

\title{
MORPHOLOGICAL FEATURES OF ENDOMETRIUM IN WOMEN OF REPRODUCTIVE AGE: ANALYSIS OF MORPHOMETRIC INDICATORS
}

\author{
๑G. M. Chornenka', M. V. Logach² \\ I. Horbachevsky Ternopil State Medical University ${ }^{1}$ \\ Danylo Halytskyi Lviv National Medical University²
}

SUMMARY. Endometrium is the main structure in the process of implantation, which undergoes permanent morphofunctional changes, and its adequate state and pregravidar transformation are necessary conditions for normal passing of pregnancy, especially in its first trimester. The research of the features of the morphological structure of normal endometrium using modern morphometric methods is necessary for understanding the essence of the pathological processes of the fuctional layer of the uterus, the progress of which may hinder pregnancy.

Material and Methods. For morphometric researching histological preparations of the functional layer of the uterus of 20 women of reproductive age with normal endometrium in the proliferation and secretion phase were used. Serial, progressive sections of paraffin blocks, thickness 2-4 micron were carried out, and were painted according to the standard method of hematoxylinum and eosin. Measurement and analysis of the diameter of the glands of the endometrium, the thickness of the wall of the glands, the ratio of the cross-sectional area of the glands to the area of the endometrium was carried out.

Results. On the basis of morphometric research of histological preparations of the functional layer of the uterus in women of reproductive age, with a normal menstrual cycle, whose average age was $(32+10)$ years, it was found that the results of the morphological research can be used for the purpose of analytical study of both physiological and pathological transformability of human endometrium.

In the endometrium of the proliferation phase, the diameter of the glands arranged from 28.29 to $70.29 \mu \mathrm{m}$ with an IQR of 21.94. The thickness of the wall is equable and its value was $(15.02 \pm 3.61) \mu \mathrm{m}$. The ratio of the cross-sectional area of the glands to the area of the parenchyma section was equable throughout the samples and ranged from $7 \%$ to $13 \%$ with an average value of $10 \%$.

In the morphometric study, the polymorphism of the glandular endometrial structures of the secretory type is confirmed by certain indices: the diameter of the glands is $71.81(47.71 ; 83.95) \mu \mathrm{m}$ and ranges from $33.39 \mu \mathrm{m}$ to $125.02 \mu \mathrm{m}$ with an IQR of 36.24. The increase in diameter compared with the parameters of the proliferation phase is statistically significant ( $p<0.05$ with an exact value of the Man-Whitney $U=72$ criterion). At the same time, the thickness of the walls of the glands decreased somewhat and was (13.13 \pm 3.37 ), which was statistically significantly lower than the thickness index in the proliferation phase. The glands had more chaotic layout in comparison with the samples of the proliferation phase - the ratio of the cross-sectional area of the glands to the area of the parenchyma section ranged from $17 \%$ to $52 \%$ with an average of $32 \%$ (the difference is statistically significant, $p<0.05$ at the value of $\chi^{2}=97$ ).

Conclusions. The morphological structure of the endometrium of women of reproductive age is characterized not only by histological but also by morphometric differences. Thus, the data obtained by us indicate a reliable difference between the main morphometric indices of the glands of the uterine mucus in the proliferative and secretory phases of the menstrual cycle in norm.

Prospects for further research. The morphological structure of the endometrium in conditions of norm and pathology requires new approaches with the use of modern available methods neccesary to understand the nature of the pathological processes of the fuctional layer of the uterus, especially in women of reproductive age, who are addressing the infertility caused by the uterine factor.

KEY WORDS: endometrium; proliferation; secretion; reproductive age; morphometry. 